\title{
An Empirical Study about Ownership Structure on Agency Cost for National Commercial Bank
}

\author{
Xu Huimin \\ School of Economics, Wuhan Donghu University
}

Keyword: National Commercial Bank Ownership Structure Agency Cost

\begin{abstract}
With the opening of China's financial market, China's banking industry begins to face competition from the world, which requires China's reform and modernization of commercial banks. Agency costs are the core of corporate governance, and it is an important factor for directly restricting governance performance of our commercial bank. The agency problems of commercial banks are particularly complex, including the agency problems between shareholders and managers, between government and government, between shareholders and creditors, between the large shareholders and minority shareholders. The ownership structure of China's commercial banks will produce a variety of interest conflicts, which led to agency costs, so the ownership structure has an important impact on the contractual relationships between shareholders, managers and creditors, optimizing the ownership structure are an effective way to solve the principal-agent problem of the banking industry.
\end{abstract}

\section{Introduction}

Since the 21st century, the reformation and innovation of China's banking sector has made remarkable achievements, the entire banking industry has undergone a fundamental change, and it has played an important role in promoting economic and social development and strongly supports rapid economic development in China. However, compared to international standards, there is still a big gap for China's commercial banks. Compared with the corporate governance requirements of Basel Committee on Banking, It is shown that the corporate governance of Chinese commercial banks at present has many problems to deal with, such as strategic objectives and culture is not very clear, internal control mechanism is weak, incentives mainly show the short-term incentives, and information disclosure requirements are not specific enough. Agency costs is the core of corporate governance, and it is an important factor for directly restricting governance performance of our commercial bank. The agency problems of commercial banks are particularly complex, including the agency problems between shareholders and managers, between government and government, between shareholders and creditors, between the large shareholders and minority shareholders.

Reducing all kinds of agency costs between bank shareholders, managers and creditors, commercial banks in China and achieving effective corporate governance is of great significance to the development of China's banking sector which is in the process of financial liberalization. The ownership structure is an important factor for forming the principal-agent problem of China's banking sector.

\section{Variable and Sample Selection}

Variables Selection. Ownership property. This paper analyses respectively the impact that the state-owned shares and corporate shares have on China's commercial banks agency costs. Since foreign investors holding share is relatively small, and there is no universality, so the corporate shares of this study includes only domestic corporate shares ratio, excluding foreign corporate shares stake. In the analysis for the nature of equity commercial banks, we introduce only two variables: the state-owned shares (X1), calculated as the state-owned shares / total shares; corporate shares ratio (X2), calculated as domestic corporate shares / number of shares. 
Ownership concentration. This paper selects two variable to measure the ownership concentration, the first one is the share ratio of the top five shareholders(X3), which is the sum of the top five shareholders to total number of shares, the second one is Herfindah5 (X4), which is quadratic sum of the top five shareholders, and its role is to highlight the major shareholders' effect.

The first type of agency cost. The first type of agency costs represents the kind of agency costs caused by the deal between shareholders and managers. The first type of agency costs includes the hidden costs such as lazy managers, and the explicit costs such as in-office consumption. It is usually represented by selling expenses ratio, since the object of study in this paper is banking sector, we use operating expense ratio to represent the first type of agency costs (Y1 ).

The second type of agency cost. The second type of agency costs indicates agency costs between large shareholders and minority shareholders, and the agency costs between large shareholders and creditors. Such type of agency costs Literature review

Table1: variables definition

\begin{tabular}{|c|c|c|}
\hline variable & Variable name & Variable definition \\
\hline \multirow{4}{*}{$\begin{array}{l}\text { Explanatory } \\
\text { variable }\end{array}$} & \multirow{2}{*}{$\begin{array}{l}\text { State-owned shares } \\
\text { ratio(X1) } \\
\text { Cooperate shares } \\
\text { ratio(X2) }\end{array}$} & State-owned shares / the total volume of securities \\
\hline & & Cooperate shares /the total volume of securities \\
\hline & $\begin{array}{l}\text { Contribution Ratio of Top } \\
\text { five shareholders (X3) }\end{array}$ & $\begin{array}{l}\text { Contribution Ratio of Top five shareholders / the total } \\
\text { volume of securities }\end{array}$ \\
\hline & Herfindah5(X4) & $\begin{array}{l}\text { Quadraticsum of contribution ratio of top five } \\
\text { shareholders }\end{array}$ \\
\hline \multirow{2}{*}{$\begin{array}{l}\text { Explained } \\
\text { variable }\end{array}$} & $\begin{array}{l}\text { The first type of agency } \\
\operatorname{cost}(\mathrm{Y} 1)\end{array}$ & Operating expenses/operating income \\
\hline & $\begin{array}{l}\text { The second type of } \\
\text { agency cost(Y2) }\end{array}$ & $\begin{array}{l}\text { (Subprime loans +doubtful loan+loss loan)/all kinds } \\
\text { of loan }\end{array}$ \\
\hline
\end{tabular}

Sample Selection. China's commercial banks can be divided into three types: urban commercial banks, joint-stock commercial banks and state-owned commercial banks. By the end of 2015, a total of 110 commercial banks, which provides a large number of samples for the study of commercial bank capital structure, but because of the special nature of the industry, it is subject to more regulation, so the information disclosed by most commercial banks is limited, a lot of data is not available. Therefore, taking into account the availability and authenticity of the data, we use listed commercial banks as research subjects. Currently, there are four state-owned commercial banks, eight joint-stock commercial banks, and three city commercial banks have listed in China. But the time of listed is not long for seven of them, and the data is not sufficient, so we excluded them. So the study material in this paper are eight banks, which are Shanghai Pudong Development Bank, Huaxia Bank, Shenzhen Development Bank, Industrial and Commercial Bank of China, Minsheng Bank and Bank of China. Taking into account the joint-stock reform and the inconsistent listing time for various banks, we use 2013 - 2015 data to do the empirical research. Sample data include the annual data from 2013 to 2015 and there are 24 pieces of data in all. 


\section{Theoretical Hypothesis}

There Is A Positive Correlation Between State-Owned Shares And Agency Costs. State-owned shareholder is not only a regulator but also a operator, and there is a contradiction between these two kinds of identity. In another word, the interests of the operators may occur beyond the regulatory authority of agents, and the complex chain of agents of the state-owned shares make China's commercial banks lose the uniqueness of the cooperation. Therefore, the presence of state-owned shares will increase agency costs between shareholders and managers of commercial banks. Moreover, the presence of state-owned shares also weakens the regulatory motive of creditors, and breeds a large number of non-performing loans, which increases agency costs between shareholders and creditors of commercial banks.

There Is A Negative Correlation Between Corporate Shares And Agency Costs. Since foreign investors holding less shares in the banking industry, and there is no universal legal, so corporate shares in this paper include only domestic corporate shares. Theoretically speaking, because of its attempt to obtain the investment return from a long-term stable growth of the company, the corporate shareholders will actively make effort to participate in the corporate governance, and corporate shareholders generally have a good market judgment, they have more cautious attitude to investment decision in the company, and therefore I believe that the corporate shares have more ability and motivation to improve corporate governance, so their holdings will reduce agency costs between shareholders and managers.

There Is AU-Shape Correlation Between Ownership Concentration And Agency Costs. The degree of Ownership concentration is divided into three categories, namely highly concentrated, relatively concentrated and highly dispersed. The first category refers to any large shareholder holding an absolute; the second category refers to the presence of a large proportion of the controlling shareholder, but at the same time, there are some other large shareholders; the third category refers to the absence of large shareholders, and ownership and management rights are completely separated. The above three categories of ownership concentration have the separately different effects on the corporate governance. Because the external governance mechanism for the banking sector in China is imperfect, excessive concentration of ownership will increase agency costs between shareholders and creditors and small shareholders. Meanwhile, because the state-owned shares of the banking sector are too large, excessive fragmentation of the ownership structure will increase the agency costs between shareholders and managers. Therefore, only moderately concentrated ownership can absorb the advantages of them, as well as avoiding the shortcomings of them, which can constrain business and achieve business stakeholders to maximize the benefits through internal supervision and external taking over.

\section{Empirical Analysis}

This paper will respectively analyses the effect imposed on agency costs by ownership structure by commercial bank in China through two regression equations.

The Empirical Test for the Effect Imposed by Ownership Structure on the First Type of Agency Costs. According to the above analysis, this paper uses the following equation to verify the impact of China's commercial banks' ownership structure on the first type of agency costs.

$\mathrm{Y} 1=\mathrm{a} 0+\mathrm{a} 2 \mathrm{X} 3+\mathrm{a} 3 \mathrm{X} 4+\mathrm{a} 5 \mathrm{X} 1+\mathrm{a} 6 \mathrm{X} 2+\varepsilon$ (1)

This model assumes that the ownership structure is exogenous, and it reflects the short-term relationship of ownership structure and agency costs. 
Table2: the regression results of the impact of Ownership Structure on the first type of agent cost of Chinese Commercial Banks

\begin{tabular}{|c|c|c|c|c|}
\hline model & R & R2 & Adjusted R2 & Standard error of estimate \\
\hline 1 & 0.778 & 0.606 & 0.433 & 0.061 \\
\hline
\end{tabular}

\begin{tabular}{|l|l|r|r|r|r|}
\hline \multicolumn{2}{|c|}{ model } & \multicolumn{1}{|c|}{ B } & $\begin{array}{c}\text { Standard } \\
\text { error }\end{array}$ & \multicolumn{1}{c|}{ t } & Sig. \\
\hline \multirow{3}{*}{1} & constant & 3.892 & 1.227 & 3.171 & 0.006 \\
\cline { 2 - 7 } & X3 & 0.277 & 0.308 & 0.900 & 0.381 \\
\cline { 2 - 7 } & X4 & 1.768 & 0.588 & 3.005 & 0.008 \\
\cline { 2 - 6 } & X1 & 0.150 & 0.145 & -1.112 & 0.283 \\
\cline { 2 - 6 } & X2 & 0.003 & 0.174 & 0.017 & 0.987 \\
\hline
\end{tabular}

According to the value of $\mathrm{R}$ and adjusted R2,the $43.3 \%$ variation of first type of agent cost from the year 2013 to 2015 can be explained by the variation of those variable, so the fitting degree of this equation is relatively high.

At the $5 \%$ significance level, there is non-significantly positive correlation between the share-taken proportion of top five shareholders and operating expense ratio for China's commercial banks. The reason is that the major shareholders of China's commercial banks are often state-owned, and when their stakes are too large, it will cause the absence of owners. Therefore, excessive concentration of ownership for China's commercial banks would increase the cost between shareholders and managers. However, the relatively concentration of ownership can be in favor of forming an effective incentive, supervision and management mechanism, and therefore reducing the first type of agency costs.

At the 5\% significance level, Herfindah5 index (X4) and operating expenses were significantly positively correlated for China's commercial banks. This suggests that the check and balances of the top five shareholders is not in favor of reducing the cost of a first type of agent cost.

There is positively correlation between the proportion of state-owned Shares and operating expense ratio, but it can't pass t-test. The state-controlled commercial banks in China can lead to the absence of owners, which will trigger moral risk managers, and seek personal gain, in the name of national interests for personal gain, and in the end result in the increased agency costs between shareholders and managers. However, it does not pass t test, I believe that is due to the reduction of state-owned shares ratio, and our country has relaxed the requirement of state-owned shares ratio, in addition to several state-controlled banks in the past few years. It weakens the negative effects of state-owned shares. However, due to historical issues of state-owned shares, it continues to hider the improvement of the bank efficiency.

The empirical results show that there is non-significantly positive correlation between the proportion of corporate shares and the first type of agency costs for China's commercial banks. This result is inconsistent with a lot of research about the relationship between corporate shares and corporate performance. I believe the first reason is that the corporate shares in our study included only domestic corporate shares, but many enterprises in China which take the stocks of commercial banks are to obtain connected loans and obtain more financial support, but not for commercial banks regulatory governance. For another reason, most of the corporate shareholders in China's commercial banks are from other industries, which may lack information management advantages about banking, so few of banks can get active and effective governance. Finally, the actual 
controlling shareholders of commercial banks in China are our country, so the domestic institutional investors can not intervene effectively the decision-making of the controlling shareholder.

The Empirical Test for the Effect Imposed by Ownership Structure on the Second Type of Agency Costs. According to the above analysis, this paper uses the following equation to verify the impact of China's commercial banks' ownership structure on a second type of agency costs.

$\mathrm{Y} 2=\mathrm{a} 0+\mathrm{a} 2 \mathrm{X} 3+\mathrm{a} 3 \mathrm{X} 4+\mathrm{a} 5 \mathrm{X} 1+\mathrm{a} 6 \mathrm{X} 2+\varepsilon(2)$

This model also assumes that the ownership structure is exogenous, and it reflects the short-term relationship of ownership structure and agency costs.

Table3: the regression results of the impact of Ownership Structure on the second type of agent cost for of Chinese Commercial Banks

\begin{tabular}{|l|c|c|r|r|}
\hline \multicolumn{4}{|c|}{ Model2 } \\
\hline model & R & R2 & adjustedR2 & standard error of estimate \\
\hline 2 & $0.674 a$ & 0.454 & 0.262 & 0.070 \\
\hline
\end{tabular}

\begin{tabular}{|l|l|r|r|r|r|}
\hline \multicolumn{2}{|l|}{ model } & \multicolumn{1}{c|}{ B } & \multicolumn{1}{|c|}{$\begin{array}{r}\text { Standard } \\
\text { error }\end{array}$} & \multicolumn{1}{c|}{$\mathrm{t}$} & \multicolumn{1}{c|}{ Sig. } \\
\hline \multirow{3}{*}{1} & constant & 0.132 & 0.189 & 0.698 & 0.495 \\
\cline { 2 - 7 } & X3 & 0.047 & 0.048 & 0.990 & 0.337 \\
\cline { 2 - 7 } & X4 & 0.029 & 0.091 & 0.323 & 0.751 \\
\cline { 2 - 7 } & X1 & -0.004 & 0.022 & -0.174 & 0.864 \\
\cline { 2 - 7 } & X2 & 0.030 & 0.027 & 1.127 & 0.276 \\
\hline
\end{tabular}

The regression results show that the impact, which the ownership structure has on the second type of agency cost, is less distinctiveness than that on first type of agency cost, but the impacts on the two types of agency costs are in the same direction. The ratio of corporate shares and the ratio of the top five shareholders show minor significantly correlated in the level of $10 \%$.The ratio of top five shareholders(X3) represents the ownership proportion, which the minority shareholders grasp in the company. The more minority equity grasp, the worse the liquidity of the funds is , and the lower the risk-resisting ability of the company. What's more, the higher the ownership concentration is, the greater voting rights is, the easier it is to violate the rights of minority shareholders or creditors, and finally result in non-performing loans.

There is also a non-significantly negative correlation between state-owned shares and the second type of agency cost. I believe that is because our country is still in the stage of economic transition, and legal regulatory system is not perfect. The commercial banks as an important financial intermediary of a country's economy, which directly affect the country's economy development, and of which security is closely associated with the stability of the whole social. When the state holds a certain stake in China's banking, the bank can make the government's credit as support, achieve stability of the financial system, and prevent the loss of state assets, which can be beneficial to resist the risk of financial system. In addition, there is positive correlation between corporate shares and non-performance loan rate, I believe that is because the purpose for the corporate shareholders to hold the bank shares is to obtain a loan.

Canonical Correlation Analysis. Because this article involves the relationship between multiple independent variables and dependent variables, this article will use canonical correlation analysis method to have essential analysis of the influence mechanism of agency cost of equity structure of commercial bank in china. Then comparing the statistical result with the result of the first method. Canonical correlation analysis is a statistical analysis method in multivariable statistics that can 
study the correlation between two sets of variables. In particular, it's a method that can translate the correlation of two groups of variables into the correlation of two groups of new variables without abandoning the information of the original variables. This method was originally put forward by Hotelling whose basic idea is reducing the dimension. That is to say, according to the correlation between variables and looking for one or a few integrated variables to replace the original variables, we can focus the relationship between two groups of variables on the relationship between a few of integrated variables. While we extract it, the correlation between the first pair of integrated variables should be the largest, the correlation between the second pair of integrated variables should be secondary and so on. These integrated variables is called canonical variables. The correlation coefficient between the first pair of canonical variables is called the first canonical correlation coefficient.

Suppose that random variables $\mathrm{X}=(\mathrm{X} 1, \mathrm{X} 2, \mathrm{X} 3, \mathrm{X} 4, \mathrm{X} 5), \mathrm{Y}=(\mathrm{Y} 1, \mathrm{Y} 2)$, the Variance matrix of $\mathrm{X}, \mathrm{Y}$ is

$$
\operatorname{cov}\left[\begin{array}{l}
X \\
Y
\end{array}\right]=\sum=\left[\begin{array}{c}
\sum_{11} \sum_{12} \\
\sum_{21} \Sigma_{22}
\end{array}\right]
$$

Among them, $\Sigma_{11}$ is the covariance matrix of the first group of variables, $\sum_{12}, \Sigma_{21}$ is the covariance matrix of the first and the second group of variables, ${ }_{22}$ is the covariance matrix of the second group of variables.

In order of investigating the Canonical correlation between the two groups of variables $\mathrm{X}$ and $\mathrm{Y}$, make their linear combination:

$$
\left\{\begin{array}{l}
U=a^{\prime} X=a_{1} x_{1}+\ldots+a_{5} x_{5} \\
V=b^{\prime} Y=b_{1} y_{1}+b_{2} y_{2}
\end{array}\right.
$$


$r=\operatorname{cov}(U, V) / \sqrt{\operatorname{var}(U) \operatorname{var}(V)}$

Maximizing.

Standardize random variable $\mathrm{U}$ and $\mathrm{V}$, we can get

$$
\begin{aligned}
& \left\{\begin{array}{l}
\operatorname{Var}(U)=\operatorname{var}\left(a^{\prime} X\right)=a^{\prime} \sum_{11} a=1 \\
\operatorname{Var}(V)=\operatorname{var}\left(b^{\prime} Y\right)=b^{\prime} \sum_{22} b=1
\end{array}\right. \\
& r=\operatorname{cov}(U, V)=a^{\prime} \operatorname{cov}(X, Y) b=a^{\prime} \sum_{12} b
\end{aligned}
$$

Therefore,our question is transferred that in the condition of (4), seek a,b, maximizing r. We will structure the lagrange function in terms of the calculation method of math extremum 。

$$
L=a^{\prime} \sum_{12} b-\frac{\lambda}{2}\left(a^{\prime} \sum_{11} a-1\right)-\frac{\mu}{2}\left(b^{\prime} \sum_{22} b-1\right)
$$

Seek the first order partial derivative of $\mathrm{L}$, and let it be zero, we can get the equation set:

$$
\left(\begin{array}{l}
\frac{\partial L}{\partial a}=\sum_{12} b-\lambda \sum_{11} a=0 \\
\frac{\partial L}{\partial b}=\sum_{21} a-\mu \sum_{22} b=0
\end{array}\right)
$$

By equation set(4), we can get $\lambda=a^{\prime} \sum_{11}=b^{\prime} \sum_{21}=\mu$, which is the correlation coefficient between $\mathrm{U}$ and V.Therefore, by equation set(7), we can get the value of a,b, and the typical variables $U$ and $V$. 
Besides, we need to test the significance of $U$ and $V$, Because the variables which are through the test can only be effective for economic analysis,the Statistics

$$
Q_{i}=-\left[n-j-\frac{1}{2}(p+q+1)\right] \operatorname{In}\left[\prod_{i=j}^{p}\left(1-\lambda_{i}^{2}\right)\right]
$$

If ${ }^{Q_{j}}>\mathrm{x} 2$, we can say the Canonical correlation coefficient is significant.

In this paper, $\mathrm{X}=(\mathrm{X} 1, \mathrm{X} 2, \mathrm{X} 3, \mathrm{X} 4), \mathrm{Y}=(\mathrm{Y} 1, \mathrm{Y} 2)$ is two groups of correlation variables, we will carry on the Canonical correlation analysis for sample data by the software Spss.

\section{The Research Conclusions}

According to the empirical analysis of impact which agency costs have on ownership structure, this paper draws the following conclusion.

\begin{tabular}{l|l|l|l}
\hline & $\begin{array}{l}\text { Ownership } \\
\text { concentration }\end{array}$ & $\begin{array}{l}\text { State-owned } \\
\text { shares }\end{array}$ & Coporate shares \\
\hline $\begin{array}{l}\text { The first type of } \\
\text { agency cost }\end{array}$ & $\begin{array}{l}\text { Significant } \\
\text { U-shape } \\
\text { correlation }\end{array}$ & $\begin{array}{l}\text { Non-significant } \\
\text { positive } \\
\text { correlation }\end{array}$ & $\begin{array}{l}\text { Non-significant } \\
\text { positive } \\
\text { correlationv }\end{array}$ \\
\hline $\begin{array}{l}\text { The second type of } \\
\text { agency cost }\end{array}$ & $\begin{array}{l}\text { Non-significant } \\
\text { U-shape } \\
\text { correlation }\end{array}$ & $\begin{array}{l}\text { Non-significant } \\
\text { nagetive } \\
\text { correlation }\end{array}$ & $\begin{array}{l}\text { Non-significant } \\
\text { positive } \\
\text { correlation }\end{array}$ \\
\hline
\end{tabular}

The test result of the first pair of canonical variables of the equity structure shows that the influence degree of index X3 and X4, X5 about the equity concentration is higher, and the influence degree of index X1, X2 about the nature of equity is lower. The inspection results of the first canonical variable about agent costs shows that, the main factor of agent cost is the non-performing loan ratio Y2, the second factor is operating expense ratio Y1. Because there is a highly relevant between the first pair of canonical variables, the equity concentration in the equity structure is highly correlated tothe first canonical variable of agent costs. The non-performing loans indicator in agent costs is also highly correlated to the first canonical variable of the equity structure. The consistency in quantity reflects the fundamental influence mechanism of equity structure on agent costs, and this result economically tallies with the timing of the index. It shows that the resultsof canonical correlation analysis has higher credibility.

Judging from the results of canonical correlation analysis, in terms of the equity structure, the equity concentration and the nature of equity are the primary factors that influence the agent costs. As is known to all, that state-owned shares hold a dominant position is a particular problem about the commercial bank equity structure in China. Therefore, it is one of the effective ways that can reduce the agency cost of Chinese commercial banks to effectively adjust the equity concentration and the nature of equity, and to optimize the equity structure.

\section{PolicyRecommendations}

The complex relation chain of state-owned shares is not conducive to effective governance of commercial banks of China. Therefore, on the one hand, our country should make the state-owned shares in a relatively holding position,and gradually reduce the proportion of state-owned shares, and even allow them exit when economic strength of our country becomes gradually strong and more market-oriented. Our country should clear its own property rights, change the traditional management concepts, and make the banking sector autonomous business entities. On the other hand, the banking sector can introduce institutional investors and make investors diversified. Finally, they also should pay attention to strengthen the financial system. prevent the blind privatization of state-owned assets. 


\section{References}

[1] Ang J S, Cole R A, Lin J W. (2000).Agency costs and ownership structure. the Journal of Finance,55 (1), 81-106.

[2] Ronald J. Gilson, Jeffrey N. Gordon.(2013).The Agency Costs of Agency Capitalism: Activist Investors and the Revaluation of Governance Rights.Columbia Law Review.1.1-38.

[3] Giuliano Iannotta, Giacomo Nocera, Andrea Sironi.(2007). Ownership structure, risk and performance in theEuropean banking industry. Journal of Banking \& Finance, 31 (7),.2127-2149.

[4] Lin, C; Ma, Y; Malatesta,P; Xuan, Y.(2012).Corporate ownership structure and bank loan syndicateStructure, Journal of Financial Economics,104 (1).1-22. 